\title{
The Effect Of Information System Quality And Information Quality On User Statisfaction Accounting Information System
}

\author{
Jufli Anita Ranti M \\ Department of Accounting, Univesity Of North Sumatra, Indonesia
}

\begin{abstract}
ARTICLE INFO
Article history:

Received Sep 01, 2021

Revised Oct 10, 2021

Accepted Nov 30, 2021

Keywords:

Information System Quality; Information Quality;

End User Statisfaction Of Infromation System.

ABSTRACT

The purpose of this study was to examine the influence of the quality of information and quality of information systems to the satisfaction of the end users of accounting information systems. This research model is used with reference to the model in using information technology system that is the Technology Acceptance Model (TAM) developed by DeLone and McLean. Data were collected from questionnaires given to 110 employees at Kodam I/BB as information systems user. Questionnaires were received back from 78 questionnaire respondents, and only 74 questionnaires that can be used for further analysis. Data analysis was performed using regression analysis through SPSS version 17. The results showed that the quality of information systems and information quality affects the end-user satisfaction of information system. The results showed that the quality of information system and the quality of information has a positive and significant influence on the accounting information system of user satisfaction in Kodam I/Bukit Barisan. This shows that the better the quality of information system and the quality of information applied to the level of satisfaction of users of accounting information system are getting higher.
\end{abstract}

This is an open access article under the CC BY-NC license.

\section{Corresponding Author:}

Jufli Anita Ranti M,

Department of Accounting,

University Of North Sumatra, Indonesia,

Jl. Dr. Mansur No. 9 Padang Bulan, Kec. Medan Baru, Kota Medan 20222.

Email: juflianita@gmail.com

\section{INTRODUCTION}

Within the scope of information systems, user needs for information systems must be well detected by the system designer so that the system that will be implemented in an organization can meet the needs of the users concerned. Fulfilling these user needs will later be able to provide satisfaction to users and motivate them to do a better job. With the development of technology that is able to have a great influence on various aspects of life, be it around residences, universities, the business world or in offices. Users expect the information systems department to assist them in various matters, such as hardware and software selection, system installation, troubleshooting, LAN connection, system development, and training. This expansion of responsibility can be seen from the availability of various forms of facilities such as information and assistance centers. In other words, a successful information systems department must be effective for both users and the organization. Thus, it is able to provide satisfaction to its service users.

The system is said to be successful if it has three components (benchmarks), namely system quality, system benefits and user satisfaction. In addition, today's computer-based information systems play an important role in supporting decision-making. The measure of the success of an 
information system is divided into two general categories, namely economic and personal. Economic results are meant in the form of an increase in profits or profits in a company. While personal results are not directly related to changes in profit, but lead to the satisfaction of its users and the use of the information system itself. This opinion shows that success in the development of information systems related to users is determined by the extent to which participation can lead to user satisfaction.

Delone and Mclean (1992:60-95) propose a model of information system success which consists of 6 categories, namely: system quality, information quality, usability, user satisfaction, personal influence, and organizational influence. In this study, we will use the influence between the quality of the accounting information system and the quality of the information produced and the satisfaction of users of the accounting information system. The quality of the information is related to the characteristics of the information in such a way that the output produced by the information system can be useful for its users. This results in the quality of the information system having an impact on user satisfaction. For this reason, it is hoped that the measurement of the effectiveness of this information system can be considered for information system programmers to design information systems for their companies, and can analyze how far the role of the system is to help achieve company goals. We do not want the implementation of this information system that requires very expensive costs not to have a positive impact on the company, or its utilization is not carried out optimally. A quality system will encourage the success of the system, another influence is an increase in overall performance, both concerning employees, leaders, owners, and the organization itself. In this case, a system is said to be running effectively.

\section{RESEARCH METHOD}

Researchers use this type of statistical research by using primary data obtained directly from the original source through questionnaires or written questionnaires given to users of information systems.

\subsection{Reliability Test}

Reliability analysis refers to an understanding that an instrument is reliable enough to be used as a data collection tool because the instrument is already good.

\section{a. Hypothesis testing}

Hypothesis testing was carried out with the t test used to test the effect of each independent variable, namely the quality of the information system on the dependent variable, namely user satisfaction.

\section{b. Testing Criteria}

Ho cannot be rejected (accepted) if $\mathrm{F}$ count $<\mathrm{F}$ table at $=5 \%$. Ho is rejected and $\mathrm{Ha}$ is accepted if $\mathrm{F}$ count $>\mathrm{F}$ table at $=5 \%$.

\section{c. Coefficient of Determination Test}

The coefficient of determination essentially measures how far the model's ability to explain variations in the dependent variable is. The coefficient of determination is between zero and one. The small value of the coefficient of determination means that the ability of the independent variables in explaining the variation of the dependent variable is very limited. A value close to one means that the independent variables provide almost all the information needed to predict the variation of the dependent variable.

\subsection{Data Analysis Techniques}

\section{a. Descriptive Analysis Method}

Descriptive analysis method is a way of describing and interpreting existing data so as to provide a clear picture of the problem to be studied. Descriptive analysis was carried out by researchers by distributing respondents' answers in the form of tables so as to obtain a clear picture of the distribution of respondents' answers. 


\section{b. Quantitative Analysis Method}

Researchers analyzed the data using a simple linear regression analysis method. In analyzing the data, the researcher used SPSS (Statistical Product and Service Solution) version 17 for windows.

\section{RESULTS AND DISCUSSIONS}

\subsection{Data Validity and Reliability}

A good instrument must have a high level of validity and reliability. An instrument is said to be valid if the research instrument can be used to measure what should be measured. While an instrument is said to be reliable if the research instrument, when used several times to measure the same object, will produce the same data.

Table 1. Validity for Information System Quality Variable (X1)

\begin{tabular}{cccc}
\hline $\begin{array}{c}\text { No. Item } \\
\text { Question }\end{array}$ & Rcount & Rtable & Information \\
\hline 1 & 0.832 & 0.235 & Valid \\
2 & 1.029 & 0.235 & Valid \\
3 & 0.837 & 0.235 & Valid \\
4 & 1,110 & 0.235 & Valid \\
5 & 0.942 & 0.235 & Valid \\
6 & 0.885 & 0.235 & Valid \\
7 & 0.642 & 0.235 & Valid \\
8 & 0.740 & 0.235 & Valid \\
9 & 0.829 & 0.235 & Valid \\
10 & 0.734 & 0.235 & Valid \\
11 & 0.872 & 0.235 & Valid \\
\hline
\end{tabular}

Table 2. Validity for Information Quality Variables (X2)

\begin{tabular}{cccc}
\hline No. Question Items & Rcount & Rtable & Information \\
\hline 1 & 0.781 & 0.235 & Valid \\
2 & 0.815 & 0.235 & Valid \\
3 & 0.811 & 0.235 & Valid \\
4 & 0.688 & 0.235 & Valid \\
5 & 0.735 & 0.235 & Valid \\
6 & 0.634 & 0.235 & Valid \\
\hline
\end{tabular}

Table 3. Validity for Information System User Satisfaction Variable (Y)

\begin{tabular}{cccc}
\hline $\begin{array}{c}\text { No. Item } \\
\text { Question }\end{array}$ & Rcount & Rtable & Information \\
\hline 1 & 0.688 & 0.235 & Valid \\
2 & 0.747 & 0.235 & Valid \\
3 & 0.589 & 0.235 & Valid \\
4 & 0.718 & 0.235 & Valid \\
5 & 0.662 & 0.235 & Valid \\
6 & 0.772 & 0.235 & Valid \\
7 & 0.639 & 0.235 & Valid \\
8 & 0.598 & 0.235 & Valid \\
9 & 0.820 & 0.235 & Valid \\
10 & 0.742 & 0.235 & Valid \\
11 & 0.708 & 0.235 & Valid \\
12 & 0.716 & 0.235 & Valid \\
\hline
\end{tabular}

The analysis continued with the reliability test. To test the reliability is done by comparing the value of ralpha with rtable. In the reliability test, the ralpha value is the alpha value contained in the Reliability Statistics table in the Cronbach's Alpha column. The condition is that if ralpha $>$ rtable, then the statement is reliable. The ralpha value for the information system quality assessment 
instrument, information quality and information system user satisfaction can be seen in the following table.

Table 4. Score Ralpha For Information System Quality Assessment Instruments, Information Quality And Information System User Satisfaction

\begin{tabular}{ccc}
\hline Instrument & Cronbach's Alpha & Information \\
\hline SI quality & 0.794 & Reliable \\
Information Quality & 0.762 & Reliable \\
SI user satisfaction & 0.739 & Reliable \\
\hline
\end{tabular}

From the test results, it turns out that the value of ralpha of the quality of information systems, information quality and user satisfaction of accounting information systems is greater than rtable 0.229 , so it can be concluded that all of the statements above are reliable.

\subsection{Descriptive Statistics}

Descriptive statistics in research are basically a process of transforming research data in tabulated form so that they are easy to understand and interpret (Indriantoro and Supomo, 2002). This technique is the most widely used technique to describe the data. Descriptive statistics indicate the number and percentage of respondents, objects that fall into the existing categories. This technique is usually used to provide initial information in research about the object or respondent.

The following is the result of the processed questionnaire which is a description of the research based on the respondents' answers to the statement of the independent variable and the dependent variable.

Table 5. Category Value of Respondents' Answers to Variable Statements X1

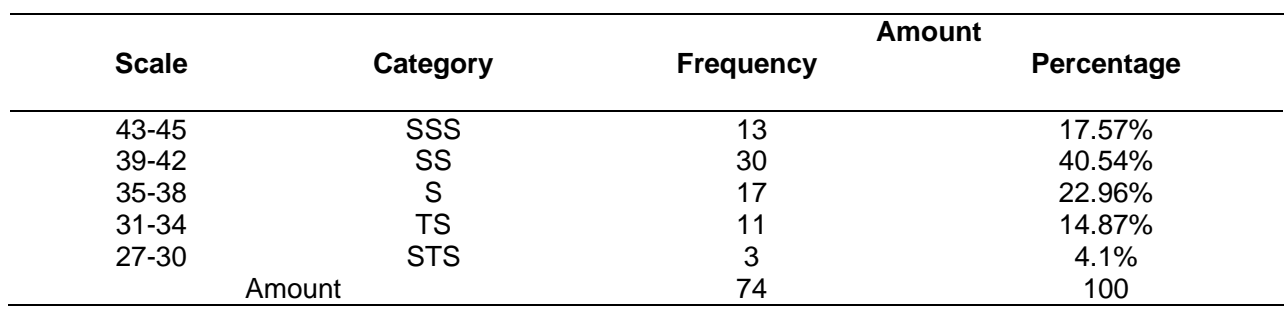

Based on the results of the answers in the table above shows that by $17.57 \%$ as many as 13 of 74 respondents answered strongly strongly agree, $40.54 \%$ as many as 30 of 74 respondents answered strongly agree, $22.96 \%$ as many as 17 of 74 respondents answered agree, $14,87 \%$ as many as 11 of 74 respondents answered disagree and $4.1 \%$ as many as 3 of 74 respondents answered strongly disagree that the quality of the information system implemented can increase data processing capacity, can be applied to other computers, adequate security system, easy to correct , easy to learn, fast access and available help facilities.

Table 6. Category Value of Respondents' Answers to Variable Statements X2

\begin{tabular}{|c|c|c|c|}
\hline \multirow[t]{2}{*}{ Scale } & \multirow[t]{2}{*}{ Category } & \multicolumn{2}{|c|}{ Amount } \\
\hline & & Frequency & Percentage \\
\hline $22-24$ & SSS & 14 & $18.92 \%$ \\
\hline $19-21$ & SS & 39 & $52.70 \%$ \\
\hline $16-18$ & $S$ & 19 & $25.68 \%$ \\
\hline $13-15$ & TS & 2 & $2.70 \%$ \\
\hline - & STS & - & - \\
\hline \multicolumn{2}{|c|}{ Amount } & 74 & 100 \\
\hline
\end{tabular}

Based on the results of the answers in the table above, it shows that by $18.92 \%$ as many as 14 of 74 respondents answered strongly strongly agree, $52.70 \%$ as many as 39 of 74 respondents answered strongly agree, $25.68 \%$ as many as 19 of 74 respondents answered agree, $2,70 \%$ as 
many as 2 of 74 respondents answered disagree and no one stated strongly disagree that the quality of the information produced is accurate, reliable, timely, relevant, easy to understand and detailed.

Table 7. Category Value of Respondents' Answers to Variable Y . Statements

\begin{tabular}{|c|c|c|c|}
\hline \multirow[b]{2}{*}{ Scale } & \multirow[b]{2}{*}{ Category } & \multicolumn{2}{|c|}{ Amount } \\
\hline & & Frequency & Percentage \\
\hline $46-49$ & SSS & 19 & $25.68 \%$ \\
\hline $42-45$ & SS & 40 & $54.05 \%$ \\
\hline $38-41$ & $S$ & 6 & $8.11 \%$ \\
\hline $34-37$ & TS & 8 & $10.81 \%$ \\
\hline $32-33$ & STS & 1 & $1.35 \%$ \\
\hline \multicolumn{2}{|c|}{ Amount } & 74 & 100 \\
\hline
\end{tabular}

Based on the results of the answers in the table above shows that by $25.69 \% 19$ of 74 respondents answered strongly strongly agree, $54.05 \%$ as many as 40 of 74 respondents answered strongly agree, $8.11 \%$ as many as 6 of 74 respondents answered agree, $10,81 \%$ as many as 8 respondents answered disagree and $1.35 \%$ as many as 1 of 74 respondents answered strongly disagree that the quality of information systems and information quality affect the satisfaction of users of accounting information systems.

\subsection{Simple Linear Regression Analysis}

Table 8. Simple Linear Regression Calculation Results Coefficientsa

\begin{tabular}{|c|c|c|c|c|c|c|c|}
\hline \multirow[t]{2}{*}{ Model } & \multicolumn{2}{|c|}{$\begin{array}{l}\text { Unstandardized } \\
\text { Coefficients }\end{array}$} & \multirow{2}{*}{$\begin{array}{c}\text { Standardized } \\
\text { Coefficients } \\
\text { Beta }\end{array}$} & \multirow[t]{2}{*}{$T$} & \multirow[t]{2}{*}{ Sig. } & \multicolumn{2}{|c|}{ Collinearity Statistics } \\
\hline & B & Std. Error & & & & Tolerance e & VIF \\
\hline (Constant) & 46,251 & 5.280 & & 8,760 & .000 & & \\
\hline $\begin{array}{c}\text { Information System } \\
\text { Quality }\end{array}$ & .226 & .116 & 219 & 9.942 & .026 & .975 & 1.026 \\
\hline Information Quality & .393 & .148 & .300 & 8,657 & .010 & .975 & 1.026 \\
\hline
\end{tabular}

From the results of these calculations, the constant value (a) is 46.251 and the value of $b 1$ is 0.226 and $b 2$ is 0.393 so that the simple linear regression equation obtained is:

$\mathrm{Y}=\mathrm{a}+(\mathrm{b} 1 \mathrm{X} 1+\mathrm{b} 2 \mathrm{X} 2)$

$Y=46,251+0,226 \times 1+0,393 \times 2$

From the above equation can be interpreted as follows:

a. It is known that the constant is 46,251 with the coefficient of information system quality (X1) and information quality (X2) is fixed/constant, so the user satisfaction value of accounting information system is 46,251 units.

b. The value of the information system quality coefficient is 0.226 , so a change in the predictor variable of information system quality (X1) by one unit will result in a positive change in user satisfaction of accounting information systems of 0.226 with the assumption that the predictor value of information quality (X2) is fixed. Thus, a positive predictor of information system quality (X1) will affect the increase in the value of information system user satisfaction. On the other hand, if there is a decrease in one unit of information system quality predictor, it will reduce the satisfaction value of accounting information system users by 0.226 units.

c. The information quality coefficient value is 0.393 , so a change in the information quality predictor variable (X2) of one unit will result in a positive change in user satisfaction of accounting information systems of 0.393 with the assumption that the predictor value of information system quality (X1) is fixed. Thus, the positive predictor of information quality (X2) will affect the increase in the satisfaction value of accounting information system users. On the other hand, if there is a decrease in one unit of information quality predictor, it will reduce the satisfaction value of accounting information system users by 0.393 units. 


\section{a. $\quad$ Test $\mathbf{R}$ Square (R2)}

To find out how much influence the quality of information systems and information quality on user satisfaction of accounting information systems can be seen through the coefficient of determination (R2) using the SPSS program in the following table.

Table 9. Calculation Results of R Square (R2)

Model Summaryb

\begin{tabular}{cccccc}
\hline Model & $\mathrm{R}$ & $\mathrm{R}$ Square & $\begin{array}{c}\text { Adjusted R } \\
\text { Square }\end{array}$ & $\begin{array}{c}\text { Std. Error of the } \\
\text { Estimate }\end{array}$ & $\begin{array}{c}\text { Durbin - } \\
\text { Watson }\end{array}$ \\
\hline 1 & $.542 \mathrm{a}$ & .617 & .492 & 1,830 & 1995 \\
\hline
\end{tabular}

Based on the results of the calculations in the table above, it can be seen that the value of $R$ Square (R2) is 0.617 or $61.7 \%$, a value of $61.7 \%$ indicates that the quality of information systems and information quality has an influence on user satisfaction of accounting information systems of $61.7 \%$, while the rest is influenced by other factors.

\section{b. Hypothesis test}

The hypothesis in this study states that the quality of information systems and information quality have an influence on user satisfaction of accounting information systems.

The results of this test show that the significance value of $t$ is smaller than the specified $(\alpha=$ $0.05)$, which is 0.679 . In addition, the results of this test also show that the t-count value is greater than the t-table value $(9.942>1.993)$ for the quality of information systems and $(8.657>1.993)$ for the quality of information. Based on the test results, it can be concluded that $\mathrm{HO}$ will be rejected and $\mathrm{H} 1$ and $\mathrm{H} 2$ will be accepted, meaning that the quality of the information system and the quality of information have a positive and significant influence on the satisfaction of users of accounting information systems.

Rejection of $\mathrm{HO}$ and acceptance of $\mathrm{H} 1$ and $\mathrm{H} 2$ can also be seen from the calculated value of $\mathrm{F}$ and table F. Based on the test results shown in the table, it can be seen that the calculated value of $\mathrm{F}$ is greater than the value of table $\mathrm{F}(37.761>3.995)$ so it can be concluded that $\mathrm{H} 0$ will be rejected and $\mathrm{H} 1$ and $\mathrm{H} 2$ will be accepted, meaning that the quality of the information system and the quality of information have a positive and significant influence. on the satisfaction of users of accounting information systems.

\section{CONCLUSION}

Every organization, including public sector organizations, is required to always improve performance. This encourages organizations to utilize information systems in carrying out their daily tasks. The application of information systems in the organization will facilitate and accelerate the completion of tasks by each individual and an adequate information system will affect the level of satisfaction of users of the information system.

The satisfaction of users of information systems implemented by an organization cannot be separated from the quality of the information system and the quality of the information produced by the system itself, so that it will determine whether the users of the system are satisfied or not.

This study examines the influence of the quality of information systems and the quality of information on the satisfaction of users of accounting information systems in this case the Management Information System Application and State Property Accounting (SIMAK BMN). The results of this study indicate that the quality of information systems and the quality of information has a positive and significant impact on user satisfaction with accounting information systems at Kodam I/BB. This shows that the better the quality of the information system and the quality of the information applied, the higher the level of user satisfaction of the information system.

Analysis of the coefficient of determination (R2) shows that $61.7 \%$ of the total level of satisfaction of information system users is influenced by the variables of information system quality and information quality, while the rest is explained by other variables outside the equation.

The sample taken by the researcher is only limited to one agency, so the conclusions of this study are not necessarily the same if the research is carried out on organizations in other sectors. And in the measurement of all variables of this study based on the perception of the respondent, so 
that it can cause problems if the perception of the respondent is not in accordance with the actual situation.

\section{REFERENCES}

Acep, Komara, 2005. Analisis Faktor-faktor yang Mempengaruhi Kinerja Sistem Informasi Akuntansi. Jurnal Ilmiah, Universitas Swadaya Gunung Jati, Cirebon.

Arikunto, Suharsimi, 2002. Prosedur Penelitian: Suatu Pendekatan praktek, Rineka Cipta, Jakarta.

Bodnar, George H dan Williams S. Hoopwood, 2000. Sistem Informasi Akuntansi, diterjemahkan oleh Amir Abadi Jusuf dan R.M. Tambunan, Edisi Keenam, Buku Satu, Salemba Empat, Jakarta.

Chusing, Barry E, 1995. Sistem Informasi Akuntansi dan Organisasi Perusahaan. Diterjemahkan oleh Ruchyat Kosasih, Erlangga, Jakarta.

Danang, Sunyoto, 2012. Analisis Validitas dan Asumsi Klasik, Cetakan I, Gava Media, Yogyakarta.

Davis, Fred D. 1988. Perceived Usefulness, Perceived Ease of Use, and User Acceptance of Information Technology, MIS Quarterly, 13(30):319-340.

DeLone, W. H., and McLean, E. R. 1992. The DeLone McLean Model Of Information System Success: A tenYear Update, Journal of Management Information, Volume 19 Nomor 4, halaman 9-30.

Edi Purnomo, 2002. Sistem Analis, Andi Offset, Yogyakarta.

Buku Pedoman Penulisan Skripsi dan Ujian Komprehensif Program Strata Satu (S1), Fakultas Ekonomi Universitas Sumatera Utara.

Hall, James A, 2001. Sistem Informasi Akuntansi, Jilid 1, Edisi Pertama, Salemba Empat, Jakarta.

Ikatan Akuntan Indonesia, 1999. Standard Akuntansi Keuangan, Salemba Empat, Jakarta.

Istianingsih dan Setyo Hari Wijanto, 2008. "Pengaruh Kualitas Sistem informasi, Kualitas Informasi, dan Percived Usefulness Terhadap Kepuasan Pnegguna Software Akuntansi". Simposium Nasional Akuntansi IX, Pontianak.

Jogiyanto H. M, 2001. Analis dan Desain Sistem Informasi: Pendekatan Terstruktur Teori dan Praktek Aplikasi Bisnis, Edisi Kedua, Andi, Yogyakarta.

Mega Purwandari, 2009. "Pengaruh Partisipasi Terhadap Kepuasan Pemakai dalam Pengembangan Sistem Informasi dengan Kompleksitas Tugas, Kompleksitas Sistem dan Pengaruh Pemakai Sebagai Moderating Variabel", Jurnal IImiah, Universitas Muhammadiyah, Surakarta.

Mulyadi, 2001. Sistem Akuntansi, Edisi Ketiga, Salemba Empat, Jakarta. Nazir, Mohammad, 1999. Metode Penelitian, Ghalia Indonesia, Jakarta.

Prito Tejokusumo, 2009. "Faktor-faktor yang Memepengaruhi Kinerja Sistem Informasi Akuntansi pada PD. BPR Bank Pasar Surakarta", Jurnal IImiah Universitas Muhammadiyah, Surakarta.

Sunarti Setianingsih, 1998. "Keberhasilan Pengembangan Sistem Informasi dan Faktor-Faktor Yang Mempengaruhinya", Kajian Bisnis No. 13.

Rommey, Marshal B, dan Paul John Stenbart, 2004. Sistem Informasi Akuntansi, Buku Kedua, Edisi Kesembilan, Salemba Empat, Jakarta.

Rusma Mulyadi, 1999. "Kualitas Jasa Sistem Informasi dan Kepuasan Para Penggunanya", Jurnal Bisnis dan Akuntansi Volume I No.2.

Widjayanto Nugroho, 2001. Sistem Informasi Akuntansi, Penerbit Erlangga, Jakarta. 